\title{
Profiling and Mapping of Prospective Senior High School Students on the Implementation of K12 in the Philippines
}

\author{
Rosslin John Robles \\ University of San Agustin, Philippines \\ rjrobles@usa.edu.ph
}

\begin{abstract}
$K-12$ is a 12-year program is found to be the best period for learning under basic education. It is also the recognized standard for students and professionals globally. The Philippines is implementing the K-12 Program on the early stage and the first batch of this study of Prospective Senior High School Students is crucial for the Universities to attract Grade 10 Students to enter its Senior High School. Data were gathered from different prospective High Schools to know the profile of the Junior High School students and their family status in order for the University to be prepared to welcome the first batch of Senior High/Grade 11 students.
\end{abstract}

Keywords: K-12, Mapping, Senior High School, Student Information

\section{Introduction}

It is crucial for the University of San Agustin to attract Grade 10 Students to enter its Senior High School. To do so, it is imperative that the University identify the push and pull factors that will make these students consider experiencing high school life with in a university setting two years before they actually enroll for their college degree. This opportunity for continuous university residence and exposure may make the transition from secondary to tertiary education a little bit easier and not so daunting, particularly to those residing outside the City. Thus, the University is called to strategize and provide measure so that these young people may be assisted in order for them not to experience a sense of dislocation and disruption by a move from a barangay high school to a university, from a simpler life in community of one's birthplace to a more complex web of city life; but instead, to find secondary and collegiate schooling more pleasant and fulfilling.

It is important as well for the University to know the profile of the Junior High School students (currently the Grade 8 and 9 students), and their family status in order for the University to be prepared to welcome the first batch of Senior High/Grade 11 students, and ready with qualified teachers in enough numbers, adequate classroom and instruction laboratories, and other student service and facilities.

\subsection{Objectives}

The survey will be undertaken to determine the profile of currently enrolled Grade 8 and 9 students in general and, in particular, those who intend to enter University of San Agustin SENIOR High School as prospective Grade 11 students.

Specifically, it will provide information on the following:

Received (May 25, 2017), Review Result (July 28, 2018), Accepted (August 7, 2018) 
Family status of Grade 8 and 9 students currently enrolled in CEAP -member school, "feeder" high schools, and big high schools in the city and province of Iloilo and Guimaras, in terms of:

Number of children below 18 years/going to elementary \& high school

Socioeconomic Status :

B.1 Parents' educational level and occupation

B.2 Family aggregate income- number of income earners, source of income, adequacy and regularity

B.3 Financial support from relatives and other- source and kind, frequency regularity and amount

B.4 House -type of materials, ownership

B.5 Family-owned appliances/devices

B.6 Family social activities/interest

2. Profile of Grade 8 and 9 students in terms of:

A. Educational plan upon completion of Junior High Schools

B. Push -pull factors behind their educational plans

3. Profile of respondents who plan /have intention to study in USA Senior High Schools:

3. A Percentage of respondents who intend to study in USA Senior High

School out of the total student's population surveyed per high school,

And their place of residence:

3. B Push - pull factors underlying their plan/intention to study in the University

3. C Strand of electives they prefer to take up:

3. D Degree programs they plan to pursue in college: and

3. E Concerns /problems and requirements that studying in USA will entail.

\section{Literature Review}

\subsection{K-12 Education Reform: Problems and Prospects}

The K-12 program is not only timely but also much needed considering the increased mobility among students and professionals across national borders. A basic education that is of comparable content, duration, and goals to those given in other countries would not only benefit the individual students but also the country, in general [1].

The K-12 would make high school graduates better equipped, ready, and competent to take on any of the significant life choices after their preparation from basic education. Graduates of K-12 will become more equipped with the skills and competence to work. They will be more confident to go out of the country to pursue studies or work, since the problem on accreditation or recognition will already have been addressed. They will be more ready to pursue higher education given the adequate training and academic preparation that the basic education promises [1].

However well-meant the $\mathrm{K}-12$ is, without the required legislation, the sustained collaboration among various stakeholders, the unflinching commitment of the President backed up by the hardworking team of implementers, and the full support of the industry and the parents, it is more likely to face the fate of other programs which ended when the 
term of the main proponent expired. A long-term solution, such as the $\mathrm{K}-12$, is undoubtedly most daunting but, once implemented, is sure to bring the best rewards [1].

\subsection{Enhanced K to 12 Basic Education Program: Opportunities and Challenges}

\subsubsection{What is $\mathrm{K}$ to 12 ?}

" $\mathrm{K}$ to 12 " stands for kindergarten plus 12 years of elementary and secondary education. This educational system for basic and secondary education is widely adopted around the world [2].

DepEd Secretary Armin Luistro presented the Basic Education Sector Reform Agenda (BESRA) last March in the annual membership meeting of the Philippine Business for Education (PBEd). BESRA, as a package of reform initiatives, considers $\mathrm{K}$ to 12 as the flagship reform strategy. The objective of the program is to be able to produce more productive and responsible citizens equipped with the essential competencies and skills for both life-long learning and employment [2].

From among various proposals and studies conducted to come up with an enhanced model that is suitable to the Philippine context, DepEd proposed the K-6-4-2 model or the $\mathrm{K}$ to 12 model. This model involves kindergarten, six years of elementary education, four years of junior high school (Grades 7-10), and two years of senior high school (Grades 11-12). The two years of senior high school intend to provide time for students to consolidate acquired academic skills and competencies. The curriculum will allow specializations in science and technology, music and arts, agriculture and fisheries, sports, business and entrepreneurship [2].

\subsubsection{Challenges: Issues and Concerns}

The K to 12 program stirred mixed reactions from different sectors. While supporters strongly believed that this is the key to quality basic education, critics argued that it is merely a superficial solution and does not truly address the more fundamental problems of the educational system [2].

Critics also questioned the relationship of the education cycle length and education quality. They cited studies by the Trends in International Mathematics and Science Study (TIMSS) which revealed that longer education cycles do not necessarily result in better performance of students [2].

But one of the major concerns of the critics is the additional expense to be incurred by the parents. The longer education cycle would be an added burden to households and would later on translate to higher dropout rates. While the government can provide free public education, the allowances, transportation, school supplies, and other schooling expenses are still to be shouldered by the parents [2].

Meanwhile, some are worried about the rush to implement the K to 12 program. For one, according to a study conducted by a group of researchers from the Philippine Institute for Development Studies (PIDS), the rush implementation of the program may have unintended effects on social equity if publicly funded. This is because many poor families do not reach beyond the secondary level of educational attainment. In addition, the revised curriculum is not yet fully tested. Finally, the study also raised concerns about the many reforms the DepEd is trying to implement all at the same time, including the implementation of the $\mathrm{K}$ to 12 program, which might result in similar reform failures in the past. It also expressed concern on the fact that DepEd might lose administrative concentration by spreading itself too thinly [2].

The change is two-fold. It will give focus not only to the curriculum enhancement but also to the transition management as well. The intention of $\mathrm{K}$ to 12 is not merely to add two years of schooling but more importantly, to enhance the basic education curriculum [2]. 


\subsection{A Comparative Study of the Attitudes between the Students and Teachers of Two Public Elementary Schools in Northern Mindanao toward the $K$ to 12 Curriculum Shift}

The students were positive to the implementation of the $\mathrm{K}-12$ program, they also are optimistic that it will be successful in achieving its goals. Moreover, the students are willing to invest their time and resources to undergo the program. The teachers also approve the implementation of the program. They believe that the program will effectively equip the students in the fields and careers that they have chosen. Although they are willing to embrace the program, still they find themselves not equipped to teach the students since they believe that they need more trainings [3].

Furthermore, the following are recommended: The students should continue to pursue their studies despite the change in the curriculum. Orientations about the $\mathrm{K}-12$ program should be given to the students for them to be motivated to continue their education [3].

Teachers should find ways for professional growth, especially with the current trends in education for them to be effective in their fields. Future researchers should consider looking into the other aspects of the $\mathrm{K}-12$ curriculum shift such as cognitive preparedness, environmental conditions and others [3].

\subsection{Where Does Philippine Education Go? The "K to 12" Program and Reform of Philippine Basic Education}

The Philippines launched a comprehensive reform of its basic education (the "K to 12" program) in 2012. Through this reform, the Philippines is catching up with global standards in secondary education and is attaching a high value to kindergarten. The structure, curricula, and philosophy of the education system are undergoing reform and improvement. The key points of the new policy are "preparation" for higher education, "eligibility" for entering domestic and overseas higher educational institutions, and immediate "employability" on graduating, all leading toward a "holistically developed Filipino". This policy appears admirable and timely, by it faces some pedagogical and socioeconomic problems. [4] pointed out in particular that the policy needs to address gender problems and should be combined with demand-side approaches in order to promote poverty alleviation and human development in the Philippines.

\section{Table 1. National Statistics Office (2011) Annual Poverty Indicators Survey 2010 indicating the Percentage of Population 6 to 24 years Old Not Attending School in School Year 2010-2011 and the Reason for Not Attending School}

\begin{tabular}{|c|c|c|c|c|c|c|c|c|c|}
\hline \multirow{3}{*}{$\begin{array}{l}\text { Reason for Not } \\
\text { Attending Setiool }\end{array}$} & \multicolumn{9}{|c|}{ Income Stranum (percent distribution) } \\
\hline & \multicolumn{3}{|c|}{ Both tacome Strata } & \multicolumn{3}{|c|}{ Lowest 309} & \multicolumn{3}{|c|}{ Highest $70 \%$} \\
\hline & Both & Male & Female & Both & Male & Temale & noth & Male & Jemale \\
\hline Total & 100 & 100 & 100 & 100 & 100 & 100 & 100 & 100 & 100 \\
\hline Sehootv are too fur away & 0.7 & 0.8 & 0.7 & 1.4 & 1.4 & 1.4 & 0.2 & 0.3 & 0.2 \\
\hline No school within the barangay & 0.3 & 0.3 & 0.3 & 0.7 & 0.6 & 0.8 & . & 0.1 & . \\
\hline No regular transportation & 0.5 & 0,5 & 0.5 & 0.9 & 0.7 & 1.0 & 0.2 & 0.3 & 0.2 \\
\hline High cost of education & 23.2 & 240 & 22.2 & 20.3 & 20.0 & 20.6 & 186 & 19.9 & 17.2 \\
\hline Iliness/Disability & 2.7 & 2.7 & 2.7 & 3.2 & 3.2 & 3.3 & 2.3 & 2.3 & 2.3 \\
\hline Housekeeping & 3.0 & 0.7 & 7.7 & 3.5 & 0.8 & 7.0 & 4.3 & 0.6 & 8.2 \\
\hline Marsage & 11.7 & 5.7 & 18.8 & 124 & 5.9 & 21.1 & 11.2 & 5.6 & 17.3 \\
\hline Fimployment/Look for work & 240 & 27.7 & 20.9 & 17.1 & 19.8 & 13.7 & 30.2 & 343 & 25.8 \\
\hline Lack of personal interest & 203 & 27.8 & 116 & 20.8 & 34.5 & 16.7 & 15.4 & 22.1 & 8.2 \\
\hline Canot cope wid school work & 0.0 & 1.1 & 0.18 & 1.4 & 1.4 & 1.4 & 0.6 & 0.8 & 0.4 \\
\hline Finished schooling & 0.6 & 7,1 & 12.4 & 1.3 & 0.8 & 2.0 & 158 & 12.4 & 10.5 \\
\hline Problem with schoot record & 0.3 & 0,4 & 0.1 & 0.3 & 0.4 & 0.2 & 0.3 & 0.4 & 0.1 \\
\hline Problem with birth cerifieate & 0.1 & 0.1 & 0.2 & 0.2 & 0.1 & 04 & - & 0 & - \\
\hline Too young to go to school & 0.7 & 0.7 & 0.7 & 1.2 & 1.2 & 1.3 & 0.3 & 0.4 & 0.3 \\
\hline Other & 0.3 & 0.3 & 0.3 & 0.2 & 0.2 & 0.1 & 0.4 & 0.5 & 0.4 \\
\hline
\end{tabular}




\subsection{A Geographic Information System-Based Decision Support System for Mapping Philippine's Higher Education Institutions}

A geographic information system-based decision support system called map analysis program (MAP) was developed to build wealth of geo-referenced data and information of higher education institution (HEIs) and programs for policy research development. Thematic maps as major outputs of MAP showed various indicators that are useful for higher education research, planning, and policy options for rationalization and resource management of HEIs. The use of geographic information systems and database management systems are emerging information technology approaches and served as data banking tools to share statistical data, information and knowledge among stakeholders on geographic areas and related policy issues. [5]

The user-friendly and dynamic DSS called MAP developed by the Mariano Marcos State University-Management Information Service (MMSUMIS) used indispensable information technology tools such as the GIS and DBMS. Such software can be coined as a DSS tool for statistical database banking for subsequent analyses of HEIs and their respective programs. Such DSS have provided users with the quantitative information as presented on various indicators on major performance thrusts on higher education, providing users to examine various scenarios for decision making on rationalizing HEIs within a given geographic area of interest. Such database must be accessible and available to users when and where needed, and in a form that is understandable by the user. Thus, there's a need for more strategic planning for rationalizing HEIs to identify the best location and help stem the uncontrolled growth in the number of HEIs and programs. Furthermore, there's a need to eliminate some programs that are being duplicated (with zero to low passing rates on PRC examinations on various programs) and overlapping using $50 \mathrm{~km}$ radius buffer zone should be set as standard distance of measure of buffer zones between and among HEIs. Such decision should consider temporal and trend data in four to five years on various programs.

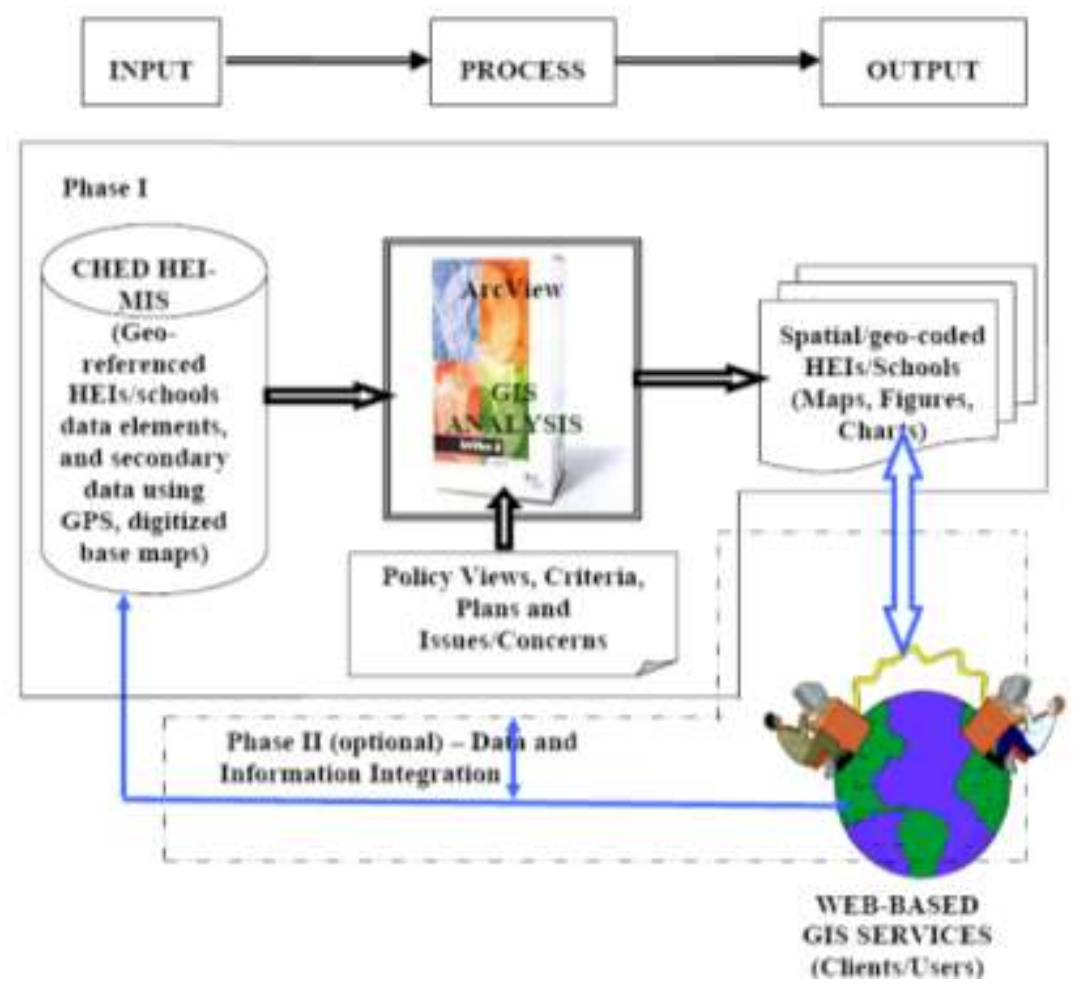

Figure 1. Conceptual Framework of the Mapping Technology 
The DSS development of MAP provides an opportunity to establish links between researchers and planners/policymakers. It is important to present the DSS to users and other experts from early stage and continues to refine based on their new ideas for improvement [5].

\section{Methodology}

\subsection{Research Approach: Descriptive Survey}

3.2. Participants: Grade 8 and 9 from the following schools:

1) Nueva valencia National High School

2) Jordan National High School

3) Anilao National High School

4) Zarraga National High School

5) Barotac Nuevo National High School

6) Pototan National High School

7) St. Augustine School - Dumangas

Survey Instruments: A 3 -page questionnaire (Appendix 1), Interview Schedule: Focus Group Discussion Guide (FGD)

\subsection{Procedure}

School Heads of 20 selected CEAP-members schools, "feeder" high schools and big high schools in Iloilo city and province and Guimaras, was informed of the survey. Upon their approval for the conduct of data gathering in their respective schools, the researchers and research assistants personally administer the questionnaire to all Grade and 9 students. They also conduct informal interviews with Grade 7-9 teachers and FDG with STUDENTS on their prevailing opinions regarding Senior High school levels of education and the common courses they think appropriate preparation for college courses.

The data was organized in preparation for statistical analysis.

3.3. Analysis: The following statistical tools were used in data treatment as required by the objectives of the study.

Percentage: (1) Prospective Grade 11 students for USA Senior High School (number of respondents who plan/ have intention to study in USA out of the total students respondents per high school and their place of residence: and (2) Number of responds who preferred to take up each of the strands of elective out of the total respondents

Frequency \& Ranking: Identification of (1) top 10 reasons/factors within the University (pull) and outside (push), underlying their choice of the University: (2) top 10 college course chosen by respondents: AND (3) top 5 problems/ concerns and requirements identified by the respondents if they choose to study in Senior High School Department of the University.

\section{Results}

The following table shows the number of respondents from different high schools: 
Table 2. Number of Respondents from Different High Schools

\begin{tabular}{|lc|}
\hline \multicolumn{1}{|c|}{ SCHOOL } & RESPONDENTS \\
\hline Nueva Valencia National High School & 62 \\
\hline Jordan National High School & 107 \\
\hline Anilao National High School & 132 \\
\hline Zarraga National High School & 98 \\
\hline Barotac Nuevo National High School & 45 \\
\hline Pototan National High School & 40 \\
\hline St. Augustine School - Dumangas & 44 \\
\hline TOTAL & 528 \\
\hline
\end{tabular}

A total of 528 respondents from 7 different high schools from Iloilo and Guimaras answered the survey. 62 from Nueva Valencia National High School, 107 from Jordan National High School, 132 from Anilao National High School, 98 from Zarraga National High School, 45 from Barotac Nuevo National High School, 40 from Pototan National High School, and 44 from St. Augustine School - Dumangas.

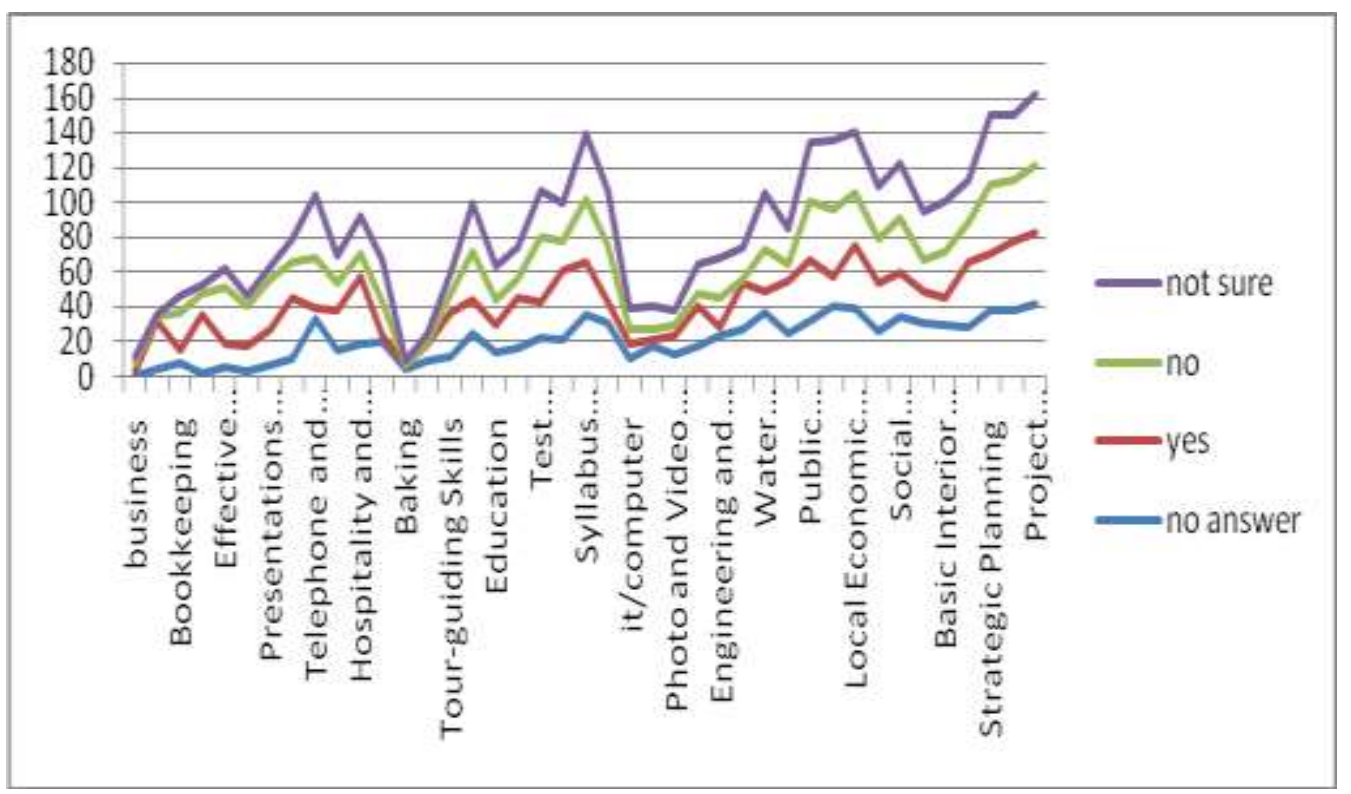

Figure 2. Number of Respondents for Short Courses

As for the short courses, the respondents preferred Accounting for Non-Accountants as the most preferred choice. Followed by Baking, Business, Essential Skills for Managers, Basic Culinary Course, Customer Relations and Handling Customer Complaints, Presentations and Public Speaking, Photo and Video Editing, Bookkeeping and Effective Promotional Strategies. 
Table 3. Rank of Short Courses

\begin{tabular}{|l|c|}
\hline Short Courses & Rank \\
\hline Accounting for Non-Accountants & 1 \\
\hline Baking & 2 \\
\hline business & 3 \\
\hline Essential Skills for Managers & 4 \\
\hline Basic Culinary Course & 5 \\
\hline Customer Relations \& Handling Customer & \\
\hline Complaints & 6 \\
\hline Presentations and Public Speaking & 7 \\
\hline Photo and Video Editing & 8 \\
\hline Bookkeeping & 9 \\
\hline Effective Promotional Strategies & 10 \\
\hline
\end{tabular}

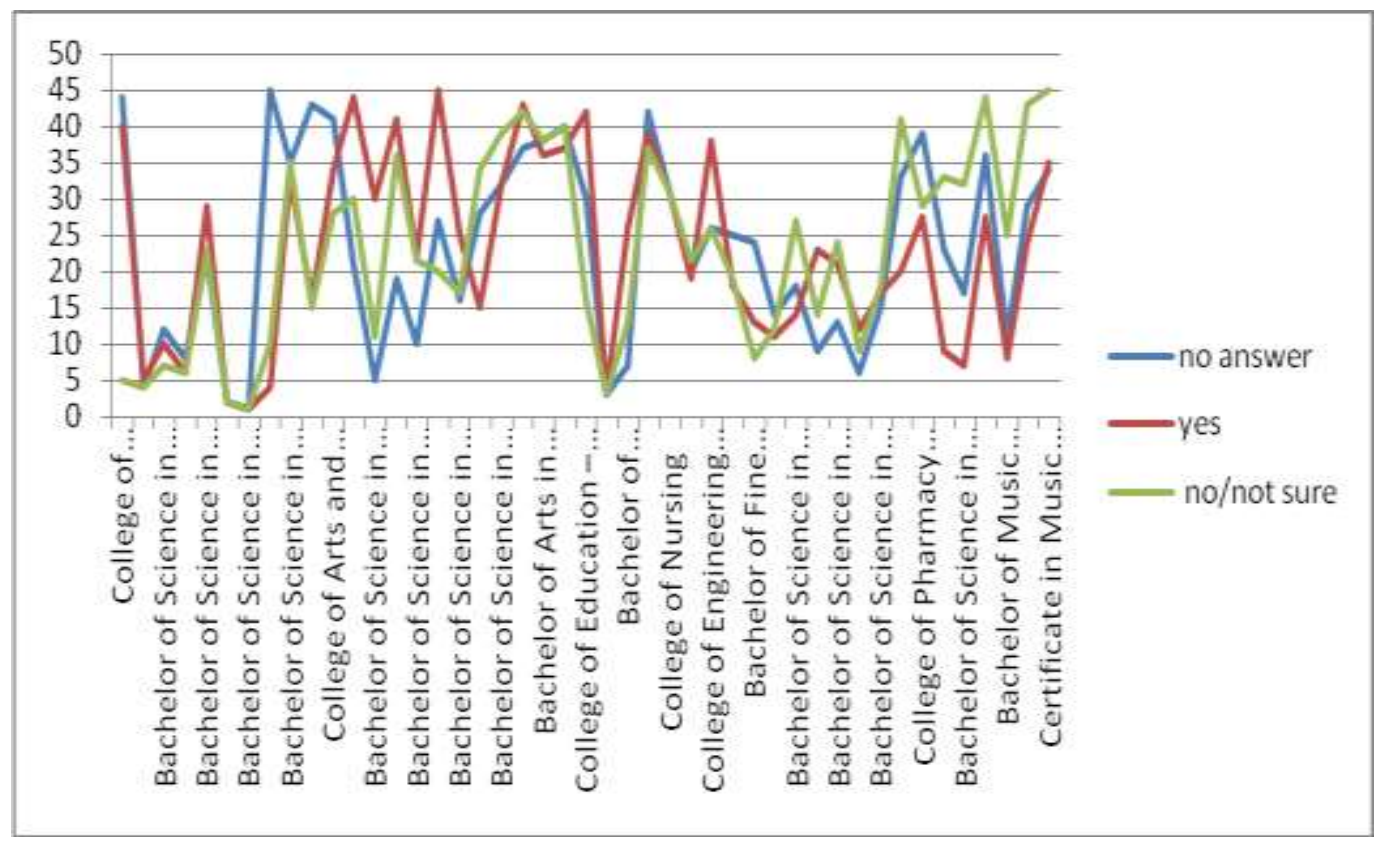

Figure 3. Number of Respondents for Courses

Among the program courses offered by the University of San Agustin, Bachelor of Science in Hotel and Restaurant Management is the most common choice followed by Bachelor of Science in Tourism Management, Bachelor of Secondary Education, Bachelor of Science in Accountancy, Bachelor of Science in Marketing Management, Bachelor of Science in Computer Engineering, Bachelor of Science in Accounting Technology, Bachelor of Science in Civil Engineering and Bachelor of Science in Information Technology. 
Table 4. Rank of Courses

\begin{tabular}{|l|r|}
\hline & Rank \\
\hline Program & 1 \\
\hline Machelor of Science in Hotel and Restaurant & 2 \\
\hline Bachelor of Science in Tourism Management & \\
\hline Bachelor of Secondary Education (English, Filipino, & 3 \\
\hline Library Science, Math, PEHM, Values Education, & 4 \\
\hline Technology and Home Economics) & 5 \\
\hline Bachelor of Science in Accountancy & 6 \\
\hline Bachelor of Science in Marketing Management & 7 \\
\hline Bachelor of Science in Computer Engineering & 8 \\
\hline Bachelor of Science in Accounting Technology & 9 \\
\hline Bachelor of Music (Music Education, Music Science, \\
Voice, Piano) & 10 \\
\hline Bachelor of Science in Civil Engineering & \\
\hline Bachelor of Science in Information Technology & \\
\hline
\end{tabular}

\begin{tabular}{|c|c|}
\hline Strind & \\
\hline No answer & 8.08 \\
GAS & 15.57 \\
TVL & 5.58 \\
Hums & 5.43 \\
ABM & 16 \\
Stem & 24.38 \\
Sports & 5.73 \\
others & 16.15 \\
maritime & \\
total & 100
\end{tabular}

\section{Percentage}

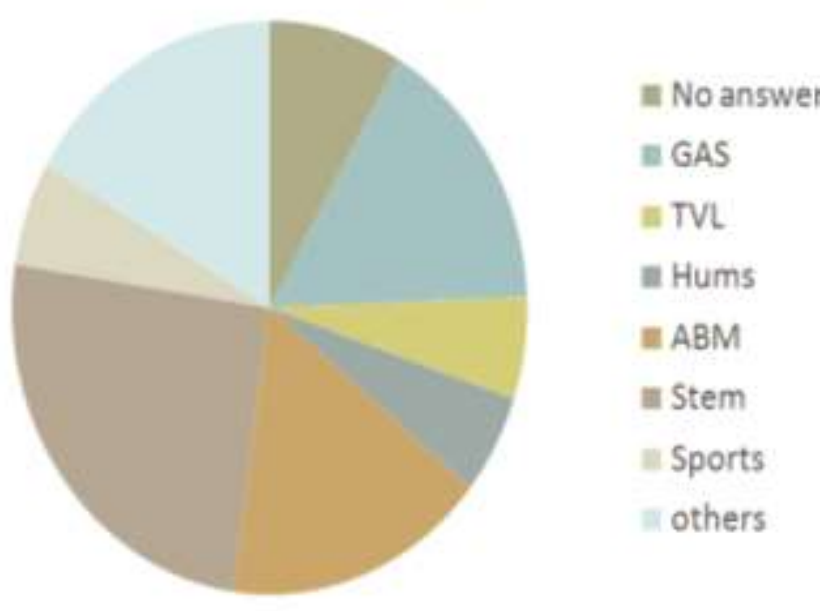

Figure 4. Strands Preferred by the Respondents

K-12 have different Strands. The Senior High School applicant should select a Strand in line with his/her interest before enrolling. Among the Strands, the following ranked among the priorities of the respondents: STEM was preferred by 24.38 percent of the respondents, ABM by 16 percent and GAS by 15.57 percent. 


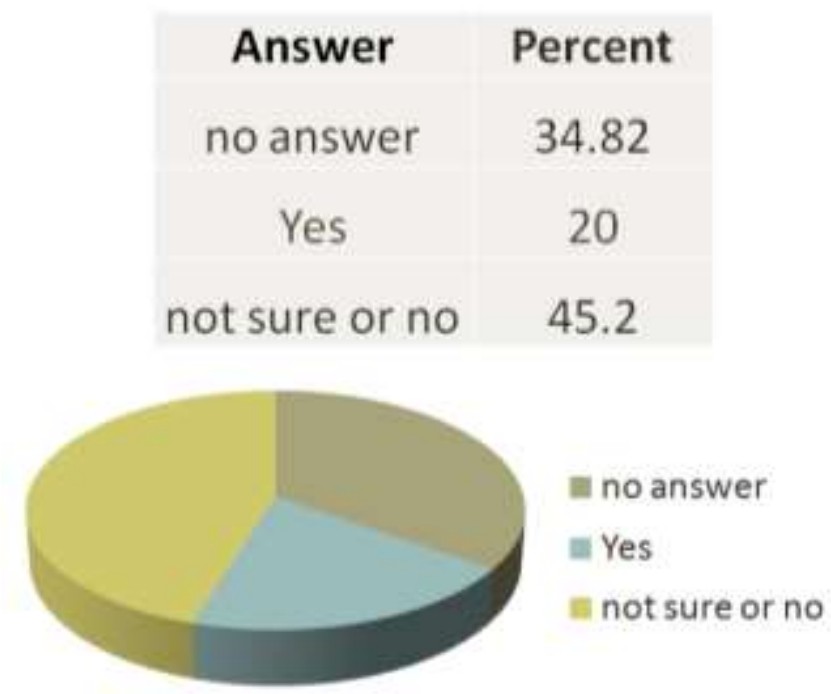

Figure 5. Respond of the Students when asked about their Interest to Study in the University of San Agustin

\section{Conclusion}

This study was conducted to determine the profile of currently enrolled Grade 8 and 9 students in general and, in particular, those who intend to enter University of San Agustin SENIOR High School as prospective Grade 11 students. Grade 8 and 9 students from the following schools served as respondents for this study: Nueva valencia National High School, Jordan National High School, Anilao National High School, Zarraga National High School, Barotac Nuevo National High School, Pototan National High School, St. Augustine School - Dumangas.

Among the program courses offered by the University of San Agustin, Bachelor of Science in Hotel and Restaurant Management is the most common choice followed by Bachelor of Science in Tourism Management and Bachelor of Secondary Education. Among the Strands, the following ranked among the priorities of the respondents: STEM was preferred by 24.38 percent of the respondents, ABM by 16 percent and GAS by 15.57 percent. When asked whether of they are interested to study in the University of San Agustin, 20 percent answered yes, 34.82 percent answered no and 45.2 percent are not sure.

\section{Acknowledgements}

This work is funded by the University of San Agustin Faculty Research Fund.

\section{References}

[1] M. Rose S. Sergio, "K-12 Education Reform: Problems and Prospects”, Gibon, ISSN 1655-7247, vol. IX, (2011), pp. 70-80.

[2] "Enhanced K to 12 Basic Education Program: opportunities and challenges", Philippine Institute for Development Studies, Economic Issue of the Day, vol. XII, no. 2, (2012) December.

[3] L. Greggory D. Crisol and J. Brian L. Alamillo, "A Comparative Study of the Attitudes between the Students and Teachers of Two Public Elementary Schools in Northern Mindanao toward the K to 12 Curriculum Shift", Presented at the DLSU Research Congress, (2014).

[4] M. Okabe, "Where Does Philippine Education Go? The "K to 12" Program and Reform of Philippine Basic education", IDE Discussion Paper No. 425, (2013) August.

[5] National Statistics Office (2011) Annual Poverty Indicators Survey, (2010).

[6] C. M. Pascual, P. M. Pasion and C. T. Ragual, "A Geographic Information System-Based Decision Support System for Mapping Philippine's Higher Education Institutions", 9th National Convention on Statistics (NCS), (2004). 